\section{References}

1. Cudworth AG, Festenstein H (1978) HLA genetic heterogeneity in diabetes mellitus. Br Med Bull 34: 285-289

2. Arnason A, Helgason T, Jensson O (1979) HLA in insulin-dependent diabetes in Iceland. Icel Med J 4: 189-190

3. Barbosa J, Ramsay RC, Knobloch WH, Cantrill HL, Noreen H, King R, Yunis E (1980) Histocompatibility antigen frequencies in diabetic retinopathy. Am J Ophthalmol 90: 148-153

4. Larkins RC, Martin FIR, Tait BD (1978) HLA patterns and diabetic retinopathy. Br Med J 1: 1111

5. Stand1 E, Dexel T, Lander T, Albert ED, Scholz S (1980) HLAantigens and diabetic retinopathy. A different view warranted. Diabetologia 18:79-80

6. Cove DH, Walker JM, Mackintosh P, Wells L, Wright AD (1980) Are HLA types or Bf alleles markers for diabetic retinopathy? Diabetologia 19: 402-403
7. Bodansky HJ, Wolf E (1981) HLA Association with diabetic retinopathy - fact or fancy? Diabetologia 20:585 (Letter)

8. Becker B, Shin DH, Burgess D, Kilo C, Miller WV (1977) Histocompatibility antigens and diabetic retinopathy. Diabetes 26 : 997-999

9. Möller E, Persson B, Sterky G (1978) HLA phenotypes and diabetic retinopathy. Diabetologia 14: 155-158

10. Dornan TL, Ting A, McPherson K, Plowright C, Mann JI, Turner RC (1981) Poor diabetic control and genetic type (HLADR4) are risk factors for retinopathy in insulin-dependent diabetics. Diabetologia 21:265 (Abstract)

Dr. R. Danielsen

Diabetic Clinic

Landspitalinn

University Hospital

Reykjavik, Iceland

\title{
Criteria for Patient Selection for Pancreatic Transplantation
}

Dear Sir,

Although the techniques of pancreatic transplantation have changed since the first clinical transplant performed in 1966 [1], the indications for using this potential modality of treatment in insulindependent diabetic patients have not been properly established. The various criteria for patient selection for pancreatic transplantation could be grouped as follows: (1) early pancreatic transplantation in patients with Type 1 (insulin-dependent) diabetes, who have not shown signs of renal involvement (serum creatinine less than $265 \mu \mathrm{mol} / \mathrm{l}$ ), but have shown definite progression of other complications, such as neuropathy, retinopathy and other signs of microangiopathy; (2) synchronous pancreatic and renal transplantation in Type 1 diabetic patients with advanced secondary complications $[2,4]$, and (3) asynchronous renal first and then pancreatic transplantation in patients with diabetic end-stage renal disease $[5,6]$.
Since the inception of our programme in January 1980 (until May 1981), we have seen 40 patients with Type 1 diabetes who have sought pancreatic tranplantation. Nineteen patients (48\%) were rejected after the initial medical assessment. Of these 19 patients, 15 had Type 1 diabetes of 6-10 years' duration with no evidence of secondary complications, and four patients had too advanced nephropathy and were referred directly for kidney transplantation. The remaining 21 patients were carefully assessed. Seventeen patients ( $42 \%$ of those initially presenting) were accepted as transplant candidates. Four patients $(10 \%)$ were rejected, three because of psychiatric unsuitability and the fourth did not have secondary manifestations of the disease.

Since rejection episodes appear to be more frequent in preuraemic diabetics than in uraemic diabetic patients receiving synchronous pancreatic and renal transplants [7], we have recently uti-

Table 1. Results of segmental pancreatic transplantation in six patients with Type 1 diabetes

\begin{tabular}{|c|c|c|c|c|c|c|c|}
\hline Patient & $\begin{array}{l}\text { Age } \\
\text { (years) }\end{array}$ & Sex & $\begin{array}{l}\text { Characteristics } \\
\text { of donor pancreas }\end{array}$ & $\begin{array}{l}\text { Pancreas - with } \\
\text { or without kidney } \\
\text { transplant }\end{array}$ & $\begin{array}{l}\text { Duration of } \\
\text { pancreas transplant }\end{array}$ & $\begin{array}{l}\text { Cause of } \\
\text { pancreas } \\
\text { removal }\end{array}$ & Survival \\
\hline 1 & 37 & M & $\begin{array}{l}\text { Cold storage }-3 \mathrm{~h} \\
\text { Hypothermic pulsatile } \\
\text { perfusion }-13 \mathrm{~h} \\
\text { Warm ischaemia - } \\
30 \mathrm{~min}\end{array}$ & Pancreas alone & $\begin{array}{l}\text { None } \\
\text { Pancreas removed } \\
2 \text { days }\end{array}$ & $\begin{array}{l}\text { Ischaemic } \\
\text { necrosis due } \\
\text { to ischaemic } \\
\text { injury and poor } \\
\text { perfusion }\end{array}$ & $\begin{array}{l}\text { Alive } \\
\text { on } \\
\text { insulin }\end{array}$ \\
\hline 2 & 20 & $\mathrm{~F}$ & $\begin{array}{l}\text { Hypothermic storage - } \\
4 \text { h } 29 \text { min }\end{array}$ & Pancreas alone & $\begin{array}{l}60 \text { days } \\
\text { Pancreas removed } \\
75 \text { days }\end{array}$ & Rejection & $\begin{array}{l}\text { Alive } \\
\text { on } \\
\text { insulin }\end{array}$ \\
\hline 3 & 28 & M & $\begin{array}{l}\text { Hypothermic storage - } \\
7 \mathrm{~h} 34 \mathrm{~min}\end{array}$ & Pancreas alone & $\begin{array}{l}36 \text { days } \\
\text { Pancreas removed } \\
48 \text { days }\end{array}$ & Rejection & $\begin{array}{l}\text { Alive } \\
\text { on } \\
\text { insulin }\end{array}$ \\
\hline 4 & 30 & M & $\begin{array}{l}\text { Hypothermic storage - } \\
7 \mathrm{~h} 7 \mathrm{~min}\end{array}$ & Pancreas alone & $\begin{array}{l}48 \text { days } \\
\text { Pancreas removed } \\
56 \text { days }\end{array}$ & Rejection & $\begin{array}{l}\text { Alive } \\
\text { on } \\
\text { insulin }\end{array}$ \\
\hline 5 & 33 & $\mathbf{F}$ & $\begin{array}{l}\text { Hypothermic storage - } \\
3 \mathrm{~h} 48 \mathrm{~min}\end{array}$ & Pancreas alone & $\begin{array}{l}40 \text { days } \\
\text { Pancreas removed } \\
46 \text { days }\end{array}$ & Rejection & $\begin{array}{l}\text { Alive } \\
\text { on } \\
\text { insulin }\end{array}$ \\
\hline 6 & 29 & M & $\begin{array}{l}\text { Hypothermic storage - } \\
18 \mathrm{~h}\end{array}$ & $\begin{array}{l}\text { Simultaneous } \\
\text { pancreas and kidney } \\
\text { transplant }\end{array}$ & $\begin{array}{l}>2 \text { months } \\
\text { Pancreas functioning }\end{array}$ & Functioning & $\begin{array}{l}\text { Alive } \\
\text { without } \\
\text { insulin }\end{array}$ \\
\hline
\end{tabular}


lized this approach rather than isolated early pancreatic transplantation as a way to improve graft survival (Table 1). We believe therefore that patients with Type 1 diabetes could be good candidates for pancreatic transplantation if they have already had a successful kidney transplant or if they have such severe diabetic nephropathy that a synchronous kidney and pancreatic transplant would be indicated.

Yours sincerely,

L. H. Toledo-Pereyra

\section{References}

1. Kelly WD, Lillihei RC, Merkel FK, Idezuki Y, Goetz FC (1967) Allotransplantation of the pancreas and duodenum along with the kidney in diabetic nephropathy. Surgery 61:827-837

2. McMaster P, Gibby OM, Calne RY, Loke SP, Luzio SD, Rolles K, White DJG, Evans DB (1980) Human pancreatic transplantation - preliminary studies of carbohydrate control. Transplant Proc 8:371-373
3. Traeger J, Dubernard JM, Tauraine JL, Neyra P, Malik MC, Pillisand C, Ruitton A (1979) Pancreatic transplantation in man: A new method of pancreas preparation and results on diabetes correction. Transplant Proc 11:331-335

4. Gliedman ML, Tellis VA, Soberman R, Rifkin H, Veith FJ (1978) Long term effects of pancreatic transplant function in patients with advanced juvenile-onset diabetes mellitus. Diabetes Care 1: $1-9$

5. Sutherland DER, Goetz FC, Najarian JS (1980) Clinical segmental pancreas transplantation without duct anastomosis in diabetic renal allograft recipients. Diabetes 29: 10-18

6. Goetz FC (1980) Early experiments in human pancreas transplantation. Diabetes 29:1-2

7. Groth CG, Lundgren G, Ostman J, Gunnarson R (1980) Experience with nine segmental pancreatic transplantation in preuremic patients in Stockholm. Transplant Proc 12: 68-71

\author{
L. H. Toledo-Pereyra \\ Department of Surgery \\ Mount Carmel Mercy Hospital \\ Detroit, MI 48235, USA
}

\section{Pancreatic Transplantation and the Artificial Pancreas}

Dear Sir

I was impressed by the in-depth studies performed by Drs. Strubbe and van Wachem to investigate the physiological role of the autonomic nervous system on insulin secretion (Diabetologia $20: 228-236$ ). Their model is elegant and gave results which enabled them to discuss the possibility that the delayed insulin response in the transplanted rats resembled the insulin response of human prediabetics in whom a lower first phase response with a delayed and sometimes higher second phase response is seen. I was particularly struck when the authors speculated that not only the early phase insulin release seems to be of physiological importance in glucose homeostatis, but also the second phase release. These studies in a transplanted animal model confirm for the first time observations which we made on pancreatectomized dogs treated with an artificial endocrine pancreas [1].

In those studies, we observed that standardised glucose challenges consisting of uniform infusions of $10 \mathrm{mg}$ glucose $\mathrm{kg}^{-1} \mathrm{~min}^{-1}$ for $60 \mathrm{~min}$ resulted in a glycaemic response to the challenge resembling mild maturity-onset diabetes. When the device was programmed to respond not only to the level of glycaemia, but also to the rate of change of glycaemia, the abnormal rise in glycaemia was prevented. The studies with the artificial pancreas indicated that an anticipatory action of the endocrine pancreas was instrumental in achieving the fine regulation seen in healthy subjects. It is interesting that the work of Strubbe and van Wachem indicated clearly that the absence of input from the autonomic nervous system on insulin secretion which occurs when pancreas is transplanted results in similar abnormalities.

In some ways it is rather disappointing that the transplanted pancreas and the closed-loop artificial pancreas both appear to suffer from the deprivation of the neurological input from the autonomic nervous system. It will be interesting to see whether the open-loop device which uses neurological inputs of a higher order, from the central nervous system as it were, will in fact be able to overcome this significant deficiency.

Yours sincerely,

A. M. Albisser

\section{Reference}

1. Albisser AM, Leibel BS, Ewart TG, Davidovac Z, Botz CK, Zingg W (1974) An artificial endocrine pancreas. Diabetes 23: 389-396

A. M.Albisser, Ph.D.

Division of Biomedical Research

The Hospital for Sick Children

Toronto M5G 1X8, Canada 